16 a 18 de outubro de 2019 - Campinas | Brasil

\title{
Liderança ideal: percepção de graduandos em enfermagem
}

\section{Luciana de Oliveira*, Kátia Stancato, Renata Cristina Gasparino}

\section{Resumo}

Objetivo: identificar o estilo de liderança que os alunos de um curso de graduação em enfermagem acreditam ser o ideal para a prática profissional e comparar se existem diferenças na percepção desses alunos ao longo da sua formação. Método: pesquisa descritiva, transversal e com abordagem quantitativa, realizada em uma Faculdade de Enfermagem de uma instituição pública do interior do estado de São Paulo. Amostra composta por 106 acadêmicos. Para a coleta dos dados foram utilizadas ficha de caracterização da amostra e o Instrumento Grid \& Liderança em Enfermagem: comportamento ideal. Foram calculadas as medidas de dispersão das variáveis contínuas e frequências das categóricas. Resultados: as médias encontradas variaram entre 17,2 e 19,0 para o estilo 9,9; entre 15,4 e 15,9 para o estilo 5,5; entre 13,8 e 14,6 para o estilo 1,9; entre 8,7 e 9,7 para o estilo 1,1 e 7,7 e 8,9 para o estilo 9,1. Na comparação entre os anos, os valores de $p$ foram superiores a 0,05 . Conclusão: o estilo de liderança ideal identificado pelos alunos do curso de enfermagem foi o 9,9, seguido dos estilos 5,5 e 1,9. Não houve diferenças significantes na percepção dos alunos ao longo dos anos do curso.

\section{Palavras-chave:}

Liderança; Administração em enfermagem; Educação em enfermagem.

\section{Introdução}

A liderança é consolidada como uma competência indispensável na prática profissional do enfermeiro e, por isso, o seu ensino durante a graduação é de fundamental importância(1). Diante do exposto, o objetivo do presente estudo foi identificar o estilo de liderança que os alunos de um curso de graduação em enfermagem acreditam ser 0 ideal para a prática profissional e comparar se existem diferenças na percepção desses alunos ao longo dos anos da sua formação.

\section{Método}

Pesquisa descritiva e transversal cuja amostra foi composta por acadêmicos de enfermagem que aceitaram participar. Foram utilizadas uma ficha de caracterização da amostra e o Instrumento Grid \& Liderança em Enfermagem: comportamento ideal, composto por 25 proposições, distribuídas em duas dimensões: orientação para produção e orientação para pessoas ${ }^{(2)}$. A inter-relação dos escores dessas orientações resultam em cinco estilos de liderança ${ }^{(3)}$. As comparações da percepção dos alunos, nos diferentes anos, foram avaliadas pelo teste de Kruskal Wallis.

\section{Resultados}

A amostra foi de 106 alunos, cuja média de idade foi de 21,1 anos. Do total, $92,4 \%$ eram do sexo feminino, $20,7 \%$ técnicos e $9 \%$ auxiliares de enfermagem, tendo $18,9 \%$ atuado profissionalmente na área. Dentre os alunos, 24,5\% atuaram em cargos de gestão, 29,2\% conheciam algum estilo de liderança, $61,3 \%$ já tinham tido contato com o tema na graduação e $62,3 \%$ já tinham tido contato com o tema em atividade prática. As comparações entre as percepções dos alunos sobre o estilo de liderança ideal estão representadas na tabela 1.

Tabela 1. Comparação entre os estilos de liderança identificados pelos alunos de um curso de graduação em enfermagem, por semestre.

\begin{tabular}{lcccc}
\hline Variável & n & Média & Destio padräo & p-valor* \\
\hline Estilo 9,1 & & & & 0,0393 \\
Primeiro semestre & 26 & 8,6 & 1,6 & \\
Terceiro semestre & 15 & 8,7 & 1,5 & \\
Quinto semestre & 24 & 7,8 & 2,1 & \\
Sétimo semestre & 27 & 7,7 & 1,7 & \\
Nono semestre & 14 & 8,9 & 1,8 & \\
Estilo 1,1 & & & & 0,3919 \\
Primeiro semestre & 26 & 9,0 & 1,5 & \\
Terceiro semestre & 15 & 9,7 & 2,1 & \\
Quinto semestre & 24 & 9,6 & 1,8 & \\
Sétimo semestre & 27 & 8,7 & 1,5 & \\
Nono semestre & 14 & 8,9 & 1,5 & \\
Estilo 5,5 & & & & 0,6399 \\
Primeiro semestre & 26 & 15,9 & 2,3 & \\
Terceiro semestre & 15 & 15,7 & 1,1 & \\
Quinto semestre & 24 & 15,7 & 1,8 & \\
Sétimo semestre & 27 & 15,4 & 1,7 & \\
Nono semestre & 14 & 15,7 & 1,7 & \\
Estilo 1,9 & & & & 0,8545 \\
Primeiro semestre & 26 & 14,3 & 1,9 & \\
Terceiro semestre & 15 & 14,0 & 1,4 & \\
Quinto semestre & 24 & 14,6 & 2,8 & \\
Sétimo semestre & 27 & 14,1 & 1,8 & \\
Nono semestre & 14 & 13,8 & 2,0 & 0,1083 \\
Estilo 9,9 & & & & \\
Primeiro semestre & 26 & 18,4 & 1,1 & \\
Terceiro semestre & 15 & 19,0 & 1,2 & \\
Quinto semestre & 24 & 18,2 & 1,8 & \\
Sétimo semestre & 27 & 18,5 & 1,0 & \\
Nono semestre & 14 & 17,2 & 2,20 & \\
\hline & & & & \\
\hline
\end{tabular}

\section{Conclusões}

O estilo de liderança ideal identificado pelos alunos do curso de graduação em enfermagem foi o 9,9, seguido dos estilos 5,5 e 1,9. Não houve diferenças significantes na percepção dos alunos, ao longo dos anos do curso.

\section{Agradecimentos}

Programa Institucional de Bolsas de Iniciação Científica $\mathrm{CNPq}$

1. Ministério da Educação (Brasil). Resolução CNE/CES №. 3, de 07 de novembro de 2001. Institui diretrizes curriculares nacionais do curso de graduação em enfermagem. Diário Oficial da união 09 nov 2001; Seção 1.

2. Trevizan MA, Mendes IAC, Hayashida M, Galvão CM, Cury SRR. Analysis of expectations on the nurse's leadership under the light of Grid theories. Rev Gau Enferm 2001 jan;22(1): 20-9. 